\title{
Bariery w życiu codziennym i ich wplyw na jakość życia osób z niepelnosprawnościami
}

PRZEGLĄD KRYTYCZNY

2021 / 3(2): 51-64

ISSN: 2657-8964

DOI: $10.14746 /$ pk.2021.3.2.3

\author{
Patrycja Szulc ${ }^{1}$ \\ ${ }^{1}$ Uniwersytet im. Adama Mickiewicza w Poznaniu, Wydział Socjologii, Szamarzewskiego 89 C, 60-568 Poznań. ORCID: \\ 0000-0001-6587-0275, Email: patszu4@st.amu.edu.pl
}

STRESZCZENIE: Celem pracy jest określenie trudności, z jakimi borykają się jednostki z różnymi rodzajami niepełnosprawności oraz ich negatywnych skutków, wśród których wymienić można: ograniczenie możliwości uczestnictwa w życiu kulturalnym, społecznym i realizowaniu się w życiu zawodowym, utrudniony dostęp do dóbr społecznie pożądanych oraz obniżenie poziomu zadowolenia z życia tych jednostek. Uwaga zostanie skupiona przede wszystkim na określeniu wpływu barier na życie jednostek z niepełnosprawnością. W tym celu dokonam analizy materiałów zastanych, w których uwzględnione zostały utrudnienia, z którymi muszą się one mierzyć oraz sposobu, w jaki wpływają one na samopoczucie i całokształt życia jednostek. Określone zostaną sposoby ułatwiania jednostkom niepełnosprawnym aktywnego uczestnictwa w życiu społecznym oraz korzystania z dóbr na równi z osobami pełnosprawnymi z uwzględnieniem roli państwa $\mathrm{w}$ tym aspekcie: opisany zostanie kluczowy dokument zapewniający osobom z niepełnosprawnościami dostęp do dóbr, tj. Ustawa z dnia 19. lipca 2019 r. o zapewnianiu dostępności osobom ze szczególnymi potrzeb.

SŁOWA KLUCZOWE: niepełnosprawność, bariery architektoniczne, bariery społeczne, jakość życia, dostęp do dóbr

\section{WPROWADZENIE: DEFINICJA NIEPEŁNOSPRAWNOŚCI}

7 godnie z definicją autorstwa Światowej Organizacji Zdrowia niepełnosprawność stanowi ograniczenie bądź całkowity brak zdolności do podejmowania pewnego rodzaju aktywności, a także ograniczenie zdolności do uczestnictwa w różnych obszarach życia, będące wynikiem wystąpienia uszkodzenia bądź upośledzenia funkcji organizmu. W zawartej na stronie rpo.gov.pl Konwencji o Prawach Osób Niepełnosprawnych uchwalonej trzynastego grudnia 2006 roku przez ONZ niepełnosprawność jest opisywana jako stan, w którym jednostka boryka się z ograniczeniem sprawności 
różnych funkcji organizmu, które wchodzą w interakcje z rozmaitymi barierami oraz w znaczny sposób utrudniają jednostkom z niepełnosprawnością aktywne uczestnictwo w różnych sferach życia. Uwzględniając rodzaj upośledzenia funkcji organizmu i będące ich rezultatem ograniczenia w codziennym funkcjonowaniu wyróżnia się niepełnosprawność intelektualną spowodowaną upośledzeniem umysłowym, niepełnosprawność sensoryczną, która przejawia się w zaburzeniach mowy, głosu, a także chorobami wzroku i słuchu, niepełnosprawność społeczną, niepełnosprawność fizyczną wynikającą z upośledzenia narządu ruchu oraz złożoną, na którą składa się kilka rodzajów niepełnosprawności - przy czym problem może sprawić przypisanie jednostki do konkretnej kategorii z powodu współwystępowania różnych zaburzeń (Rzempowska 2011: 25)

W naukach społecznych niepełnosprawność postrzegana jest jako dynamiczny proces, gdzie ważną rolę, obok ograniczeń wynikających z fizycznych uszkodzeń organizmu, odgrywają czynniki, do których zalicza się indywidualne cechy jednostki z niepełnosprawnością, a także warunki środowiska, w jakim ona funkcjonuje (Konarska 2019: 21). Tym, co poniekąd wpisane jest w definicję niepełnosprawności są bariery towarzyszące codziennemu funkcjonowaniu osób z niepełnosprawnością - w artykule zostanie podjęta próba określenia wpływu barier na całokształt życia jednostki z uwzględnieniem możliwości zaspokojenia podstawowych potrzeb jednostek z niepełnosprawnością. W tym celu zostanie dokonana analiza materiałów zastanych, czyli przeprowadzonych na grupie osób z niepełnosprawnością badań dotyczących barier, które napotykają w swym życiu osoby niepełnosprawne. Ponadto, przytoczę możliwe sposoby zapobiegania dyskryminacji osób z niepełnosprawnością.

\section{SPECJALNE POTRZEBY OSÓB Z NIEPEŁNOSPRAWNOŚCIAMI W KONTEKŚCIE DOBROBYTU SPOŁECZNEGO}

Osoby z różnymi rodzajami niepełnosprawności narażone są na istnienie utrudnień w życiu codziennym, które mogą skutkować obniżeniem jakości ich życia oraz rzutować na szeroko rozumiany dobrobyt społeczny tych jednostek. Jednostki z niepełnosprawnością ruchową, sensoryczną bądź intelektualną, zazwyczaj nie mają możliwości pełnego uczestnictwa w życiu społecznym na równi z osobami pełnosprawnymi, co może stanowić rezultat istnienia barier natury fizycznej, społecznej, edukacyjnej bądź kulturowej, które wpływają na sposób postrzegania jednostek niepełnosprawnych w społeczeństwie oraz przyczyniają się do ich marginalizacji (Maciarz A. 2003: 196-201). Na pojęcie dobrobytu jednostki składa się szereg własności, które wyznaczają stopień pomyślności jej życia, wśród których wymienić można doświadczanie określonych stanów psychicznych takich jak radość, czy spełnienie, a także możliwość zaspokojenia pragnień (Zaremba 2016: 325-326). Filozoficzne teorie dobrobytu obejmują natomiast teorie stanów psychicznych, które zakładają, iż dobrem człowieka jest doświadczanie określonych stanów psychicznych, teorie pragnień według których dobrobyt człowieka polega na zaspokajaniu pragnień oraz teorie list obiektywnych, zgodnie z którymi „istnieją z góry określone proporcje, które decydują o tym, że określone rzeczy są dobre dla człowieka, niezależnie od tego czy są one przedmiotem jego pragnień lub czy 
dają szczęście” (Ibidem: 325).

Zaspokojenie różnego rodzaju potrzeb umożliwia tym jednostkom uczestnictwo w różnych obszarach życia na równi z osobami pełnosprawnymi, co wpływa na dobrobyt społeczny tychże osób, który definiuje się jako stopień zaspokojenia potrzeb materialnych oraz niematerialnych (Twardowski 2018: 104-105). Osoby niepełnosprawne doświadczają rozległych problemów w wielu istotnych obszarach codziennego funkcjonowania (Zielińska-Więczkowska, Ziółkowska 2014: 107). Jednostka z niepełnosprawnością napotyka w ciągu trwania życia na rozmaite utrudnienia, wśród których wymienić można nie tylko bariery architektoniczne istotne z punktu widzenia osób z niepełnosprawnością ruchową, lecz także bariery komunikacyjne związane z utrudnieniami w komunikacji (wynikające ze specjalnych potrzeb, które dotyczą kwestii takich jak konieczność przystosowania przestrzeni do poruszania się przy użyciu wózka inwalidzkiego) oraz społeczne, do których powstawania przyczynia się negatywny sposób postrzegania jednostek z określonym rodzajem niepełnosprawności przez społeczne otoczenie, w którym dana jednostka wychowuje się i żyje. Utrudnienia te są skorelowane z posiadanym przez konkretną jednostkę rodzajem niepełnosprawności oraz przyczyniają się do utrudnień w realizacji pragnień oraz obniżenia jej zadowolenie z życia, co sprawia, iż jednostka nie doświadcza pewnych stanów psychicznych (takich jak radość, samospełnienie), co z kolei wpływa na jej subiektywne odczucie dobrobytu.

Brak możliwości zaspokojenia potrzeb istotnych z punktu widzenia jednostki oraz niemożność uczestnictwa w życiu społecznym jest zdaniem niektórych autorów tym, co czyni jednostkę z uszkodzeniem ciała niepełnosprawną. Można więc wywnioskować, iż niepełnosprawność jest wytworem społeczeństwa, które stygmatyzuje jednostkę ze względu na jej ograniczoną sprawność oraz konieczność mierzenia się z barierami fizycznymi, jak również społecznymi (Admin Rampy, Potrzeby osób z niepełnosprawnościa w zakresie pokonywania barier. Pobrane z: https://rampa.net.pl/potrzeby-osob-niepelnosprawnych-w-zakresie-pokonywania-barier). Warto przyjrzeć się bliżej kwestii utrudnień, z którymi muszą zmagać się jednostki z niepełnosprawnościami, bowiem bariery, które napotykają w codziennym życiu osoby niepełnosprawne w znaczny sposób utrudniają osiągnięcie przez nie niezależności, a także ograniczają możliwość aktywnego udziału w życiu społecznym oraz wchodzenia w interakcje z innymi ludźmi. Bariery funkcjonalne wiążą się również z „brakiem dostępności bądź utrudnieniami w korzystaniu przez osobę niepełnosprawną z przestrzeni życiowej” (Ibidem.), co w znaczny sposób może przyczynić się do obniżenia poziomu zadowolenia z życia danej jednostki, a także sprawić, iż zacznie ona porzucać różne formy aktywności (Zielińska-Więczkowska, Ziółkowska 2014: 107). W rezultacie może to skutkować obniżonym poczuciem własnej wartości wynikającym z ciągłego porównywania się do osób, które w swoim codziennym życiu nie są narażone na stały kontakt z utrudnieniami. To właśnie pojawienie się barier fizycznych takich jak brak możliwości szybkiego dostania się do budynków ze względu na brak ich dostosowania do potrzeb osób z niepełnosprawnością ruchową oraz społecznych będących rezultatem powielania negatywnych stereotypów i dyskryminacji jest tym, co czyni jednostkę niepełnosprawną. 


\section{BARIERY ORAZ ICH WPLYW NA JAKOŚĆ ŻYCIA OSÓB Z NIEPEŁNOSPRAWNOŚCIĄ}

Osoby niepełnosprawne napotykają na różnego rodzaju bariery, które są ściśle powiązane z rodzajem przejawianej przez nie niepełnosprawności. Osoby z niepełnosprawnością ruchową, w tym osoby poruszające się przy pomocy wózka inwalidzkiego zmagają się z utrudnieniami architektonicznymi wynikającymi z braku dostosowaniu budynków użyteczności publicznej do ich rodzaju niepełnosprawności. Problematyczny dla osób z niepełnosprawnością ruchową może okazać się brak podjazdów dla osób poruszających się przy pomocy wózka inwalidzkiego, niedostosowanie środków transportu publicznego oraz budynków użyteczności publicznej do potrzeb jednostek z niepełnosprawnością ruchową, brak odpowiednich wind, zbyt wąska przestrzeń czy brak toalet wyposażonych w podnośniki oraz parkingów dostosowanych dla potrzeb osób z niepełnosprawnością ruchową. (Regionalny Ośrodek Polityki Społecznej ROPS Rzeszów 2014: 12-16, 21-23). W roku 2013. Halina Zielińska-Więczkowska oraz Katarzyna Ziółkowska przeprowadziły badanie, którego celem było ukazanie utrudnień, które napotykają osoby z niepełnosprawnością w różnych sferach życia. Badanie zostało przeprowadzone na grupie 81 pacjentów Oddziału Rehabilitacji 10 Wojskowego Szpitala Klinicznego z Polikliniką SP ZOZ w Bydgoszczy. Badaczki stworzyły w tym celu kwestionariusz ankiety, która dotyczyła ważnych aspektów życia jednostek z niepełnosprawnością. Grupę poddaną badaniu stanowiły w większości osoby młode, ponad połowa ankietowanych należała do grupy osób z niepełnosprawnością ruchową. Badania wykazały, iż ankietowani jako najczęściej występujące bariery architektoniczne w środowisku ich zamieszkania wymieniały: armaturę sanitarną, wyposażenie kuchni, występowanie progów, schodów, zbyt wąskich futryn oraz pochyleń powierzchni, natomiast do barier architektonicznych najczęściej występujących poza miejscem ich zamieszkania zaliczyły one występowanie krawężników, pojedynczych stopni, obecność schodów, brak podjazdów, wind oraz miejsc sanitarnych dla osób niepełnosprawnych, jak również brak sygnalizacji i oznakowania (Zielińska-Więczkowska, Ziółkowska 2014: 108).

Osoby niewidome bądź słabowidzące odbierają otoczenie zewnętrzne za pomocą zmysłów innych niż wzrok - głównie za pośrednictwem zmysłu dotyku (Gleń, Jarocka-Mikrut 2015: 40), dużą rolę w rozeznaniu się w otoczeniu odgrywa również słuch. Bariery w życiu osób niewidomych bądź słabowidzących dotyczą więc w głównej mierze elementów architektury niedostosowanej do ich potrzeb: do głównych utrudnień zalicza się, podobnie ja w przypadku osób z niepełnosprawnością ruchową występowanie nierówności w podłożu (obecność krawężników, zbyt wąskich przestrzeni), brak informacji dźwiękowej w komunikacji publicznej bądź przestrzeni publicznej (np. przy przejściach dla pieszych, w urzędach) oraz tablic informacyjnych w języku Braille’a (Autor nieznany. Pobrane z: http://pfos.org.pl/w-swiecie-polciszy/emocje/bariery-w-zyciu-codziennym). Dla tej grupy osób z niepełnosprawnością kwestią problematyczną może okazać się robienie zakupów w wielkopowierzchniowych sklepach samoobsługowych, gdzie towary rozmieszczone są w różnych miejscach na sporej przestrzeni, ponadto położenie towaru często ulega zmianom - brak specjalnych oznaczeń, półek 
sklepowych, kas czy alejek, sprawia, że miejsca te stają się praktycznie niedostępne dla osób niewidomych bądź słabowidzących, nawet tych dobrze zrehabilitowanych. Również kasy samoobsługowe wymagające skanowania produktów często nie są dostosowane do potrzeb osób z tym rodzajem niepełnosprawności (Koprowska D, Koprowska J., Osoby niepełnosprawne wzrokowo w sklepach samoobsługowych. Pobrane z: http://www.trakt.org.pl/osoby-niepelnosprawne-wzrokowo-w-sklepach-samoobslugowych-dorota-koprowska-joanna-koprowska/). To z kolei może doprowadzić do konieczności korzystania z pomocy osób trzecich, co może skutkować odbieraniem tychże jednostek w sposób negatywny i przyczynić się do powstawania barier społecznych. Konieczność zaangażowania innych osób do pomocy w zakupach może stanowić dla jednostki niepełnosprawnej znaczne utrudnienie - może bowiem wiązać się ze stresem i dyskomfortem, wynikającym z braku wiedzy co do możliwej reakcji osoby, która zostanie poproszona o udzielenie pomocy. Na stronie fundacji Trakt została zamieszczona historia niewidomego mężczyzny w podeszłym wieku, któremu odmówiono pomocy w zrobieniu zakupów powołując się na duży ruch w sklepie. Mężczyzna zgłosił tę sytuację na policję, sprawa następnie została nagłośniona przez media. Sytuacja ta spotkała się z odpowiedzią ze strony społeczeństwa: większość ludzi była oburzona zachowaniem obsługi sklepu, część osób uznała jednak postawę mężczyzny za roszczeniową, twierdząc, iż „[...] skoro nie widzi, to nie powinien $w$ ogóle sam przychodzić do sklepu samoobsługowego" (Koprowska D, Koprowska J., Osoby niepełnosprawne wzrokowo w sklepach samoobsługowych. Pobrane z: http://www.trakt.org.pl/osoby-niepelnosprawne-wzrokowo-w-sklepach-samoobslugowych-dorota-koprowska-joanna-koprowska/). Taka postawa, nierzadko przejawiana przez osoby pełnosprawne, jest krzywdząca dla osoby niepełnosprawnej oraz może przyczynić się do wycofywania się z różnych sfer życia, a co za tym idzie - obniżać jej poziom samopoczucia, który składa się na definicję społecznego dobrobytu.

Osoby głuche bądź słabosłyszące napotykają bariery w postaci braku pętli indukcyjnych oraz tablic informacyjnych wyświetlających komunikaty w budynkach użyteczności publicznych czy środkach transportu publicznego, braku napisów dodawanych do wydarzeń społecznych czy kulturalnych czy zbyt szybka bądź niewyraźna mowa pracowników instytucjonalnych oraz innych jednostek (Autor nieznany. Pobrane z: http://pfos.org.pl/w-swiecie-polciszy/emocje/bariery-w-zyciu-codziennym/). Dostępność osób głuchych do różnych aspekty życia została opisana przez Piotra Kowalskiego, Annę Sachę oraz Monikę Szczygielską w raporcie pt Sytuacja osób głuchych w Polsce, który ukazał się w roku 2014. Autorzy do barier, z którymi muszą radzi sobie osoby z tym rodzajem niepełnosprawności zaliczyli: brak napisów dla osób niesłyszących oraz tłumaczeń na język migowy w programach nadawanych w telewizji, filmach DVD, materiałach audiowizualnych dostępnych na stronach internetowych, w transmisjach emitowanych na żywo, filmach wyświetlanych w kinach oraz wydarzeniach teatralnych. Osoby z problemami słuchu mają ograniczony dostęp do informacji publicznej: według danych $\mathrm{z}$ roku 2012 napisy dla osób niesłyszących były dodawane do 33.6\% programów emitowanych na kanale TVP1, 15.6\% na kanale TVP2, 17.6\% na kanale Polsat oraz 10.2\% na kanale TVN (Kowalski, Sacha, Szczygielska 2014: 40-41), co świadczy o tym, iż programy telewizyjne w znacznej części nie są przystosowane 
dla osób słabosłyszących oraz głuchych.

Osoby z niepełnosprawnością intelektualną spotykają się natomiast z brakiem zrozumienia ze strony innych osób, w tym pracowników administracyjnych oraz brakiem kompetencji urzędników w kontakcie z osobami z tym rodzajem niepełnosprawności. Ponadto, osoby z niepełnosprawnością intelektualną mają problem z artykułowaniem myśli oraz wchodzeniem w relacje z innymi, co nie tylko utrudnia tym osobom funkcjonowanie, lecz również przyczynia się do ich marginalizacji i wykluczenia. Funkcjonujące w społeczeństwie stereotypy na temat osób z niepełnosprawnością intelektualną oraz będący ich wynikiem lęk przed wchodzeniem w kontakty z osobami z tego typu niepełnosprawnością przyczyniają się do wytwarzania barier społecznych, które bardzo ciężko zwalczać, a które w istotny sposób wpływają na pogorszenie jakości życia osoby niepełnosprawnej ze względu na marginalizację i wykluczenie tych osób. Jak wspomina Żaneta Stelter, im jednostka rzadziej wchodzi w kontakty z niepełnosprawnymi, oraz im uboższa jest jej wiedza na temat niepełnosprawności, tym częściej powiela stereotypy oraz dystansuje się od niepełnosprawnych. Autorka twierdzi, iż „warto przełamać stereotyp bezwartościowego odmieńca i zastanowić się, czy osoba niepełnosprawna tak bardzo różni się od osoby pełnosprawnej, a jeżeli tak, to co należy zrobić, aby te różnice nie prowadziły do piętnowania tych, którzy są inni od nas, a wręcz przeciwnie, uruchamiały działania wyzwalające społeczną akceptację i zrozumienie" (Stelter 2010: 61) - z tym twierdzeniem zgadzam się całkowicie. Bariery tkwiące w umysłach powinno się bowiem zwalczać przede wszystkim poprzez różnego rodzaju działania mające na celu uświadamianie społeczeństwa czym w rzeczywistości jest niepełnosprawność intelektualna, jak zachowują się osoby z tym rodzajem niepełnosprawności oraz w jaki sposób jednostki pełnosprawne mogą przyczyniać się do poprawy samopoczucia tychże osób (Tamara, Niepełnosprawność intelektualna a bariery społeczne. Pobrane z: http://www.perioorto.pl/niepelnosprawnosc-intelektualna-a-barier/).

Wyniki badania ankietowego z roku 2014 pt. Osoba niepełnosprawna aktywnym uczestnikiem życia społecznego i zawodowego, które objęło zakłady pracy chronionej oraz zakłady aktywności zawodowej umożliwiły określenie najczęstszych problemów, z którymi zmagają się osoby z niepełnosprawnością w swoim codziennym życiu. Największy odsetek respondentów stanowiły osoby z niepełnosprawnością sprzężoną, tj. osoby, u których stwierdzono więcej niż jeden rodzaj niepełnosprawności - stanowiły one 30\% ogółu respondentów. Znaczną część ankietowanych stanowiły osoby z upośledzeniem narządu ruchu - 27\% ogółu respondentów. Badanie wykazało, iż problemy towarzyszące osobom niepełnosprawnym są zróżnicowane i w dużej mierze zależą od rodzaju niepełnosprawności oraz wiążących się z nią ograniczeń ogólnej sprawności organizmu, a także od rodzaju stopnia uszkodzenia konkretnych narządów. Badanie wykazało, iż największą trudność sprawia osobom niepełnosprawnym przemieszczanie się poza domem - odpowiedź tę najczęściej wskazywały osoby z upośledzeniem narządu ruchu, prawie jedną czwarta spośród osób, które wskazały tę odpowiedź stanowiły osoby z chorobami neurologicznymi. Druga najczęściej wskazywana w badaniu odpowiedź dotyczyła innych problemów, wśród których najczęściej wymieniano prace fizyczne, w tym dźwiganie, komunikację oraz kontakty z innymi ludźmi, załatwianie 
spraw urzędowych i przygotowywanie dokumentów oraz ból, złe samopoczucie. Do czynników utrudniających osobom niepełnosprawnym dostęp do różnych aspektów życia społecznego respondenci zaliczali: brak pracowników odpowiednio przeszkolonych do kontaktu z osobami niepełnosprawnymi, ograniczoną ofertę kulturalną, sportową, turystyczną skierowaną do osób niepełnosprawnych oraz brak sprzętu oraz wyposażenia w placówkach oświatowych dostosowanego do potrzeb osób niepełnosprawnych (Regionalny Ośrodek Polityki Społecznej ROPS Rzeszów 2014: 12-16, 21 23).

\section{ROLA PAŃSTWA W NIWELOWANIU BARIER W ŻYCIU OSÓB Z NIEPEŁNOSPRAWNOŚCIAMI}

Istotny problem w życiu osób z niepełnosprawnością może stanowić znalezienie satysfakcjonującego zatrudnienia, a także - w przypadku osób, które nie są w stanie samodzielnie wykonywać codziennych czynności - otrzymanie wsparcia od osoby sprawującej opiekę. Dlatego ważne jest, aby podejmowane były działania ze strony państwa, do których zalicza się tworzenie ustaw, które będą zapobiegały zachowaniom dyskryminacyjnym, oferowanie różnych form wsparcia (w tym wsparcia finansowego) osobom z niepełnosprawnością oraz ich opiekunom, a także odejście od polityki neoliberalnej, która działa na niekorzyść osób ze specjalnymi potrzebami. Rodzajami działań, które zyskały popularność w dobie pandemii, a których celem jest zapoznanie społeczeństwa z tematyką niepełnosprawności, w tym jej szczególnego rodzaju, do którego zalicza się niepełnosprawność intelektualna, jest organizowanie różnego rodzaju webinariów - przykładem są spotkania internetowe organizowane przez ELSA Wrocław, w których sama uczestniczę. Spotkania dotyczą różnych aspektów niepełnosprawności intelektualną, pozwalają na zapoznanie się z tą tematyką oraz w prosty sposób opisują problemy, z którymi borykają się osoby niepełnosprawne, podkreślając aspekt barier społecznych, które są krzywdzące dla jednostek z niepełnosprawnością, a także akcentując rolę państwa, które niekiedy swoimi działaniami może przyczyniać się do dyskryminacji tych jednostek - przykładem, który utkwił mi w pamięci, jest zakaz ślubu dwojga osób z niepełnosprawnością intelektualną w sytuacji, gdy stan zdrowia lub poziom intelektualny przejawiany przez jednostki zagraża małżeństwu bądź zdrowiu przyszłego potomstwa - takie stwierdzenie jest bowiem zapisane w art. $12 \S 1$ kodeksu rodzinnego opiekuńczego.: przykładem jest sytuacja Jolanty, kobiety z dziecięcym porażeniem mózgowym i będącym jego rezultatem niepełnosprawnością ruchową oraz Piotra, który jest osobą z upośledzeniem intelektualnym w stopniu lekkim. Pomimo tego, iż partnerzy świetnie radzą sobie w życiu codziennym, są aktywni zawodowo oraz uczestniczą w rehabilitacji, urzędnik nie zgodził się na udzielenie ślubu z powodu przejawianej przez nich niepełnosprawności. Wypowiedź Pani Jolanty zawarta na stronie polsatnews, wskazuje, iż poczuła się ona bardzo dotknięta tą sytuacją: odmowa udzielenia ślubu sprawiła, że poczuła się „jak odrzucona przez los, jak jakaś trędowata, jakby nie mogła żyć w tym społeczeństwie” (Autor nieznany, Niepełnosprawni nie mogą wziąć ślubu. Pobrane z: https://www.polsatnews.pl/wiadomosc/2019-11-17/myslelismy-ze-zostaniemy-potraktowani-jak-normalna-para-nie- 
pelnosprawni-probuja-wziac-slub/). Działania takie, w moim odczuciu nie powinno mieć miejsca w demokratycznym państwie, którego zasadniczymi celami powinna być walka z różnego rodzaju nierównościami społecznymi oraz walka z dyskryminacją wobec grup mniejszościowych.

Istotną rolą państwa demokratycznego powinno być podejmowanie działań mających na celu zwiększenie udziału jednostek z niepełnosprawnością w różnych sferach życia, uwzględnianie dobrostanu osób oraz zaprzestanie przedmiotowego traktowania jednostek z niepełnosprawnościami przez władze państwowe. Istotną rolę może odegrać tu odejście od modelu polityki neoliberalnej - tzw. „antyspołeczna polityka społeczna” wg Mariusza Baranowskiego (Baranowski 2015: 115-124) która charakteryzuje się minimalnym zaangażowaniem państwa w pomoc najsłabszym oraz stawia osoby potrzebujące w roli roszczeniowych. Partie rządzące - co jest widoczne także w Polsce - często bowiem nie biorą pod uwagę potrzeb osób z niepełnosprawnościami, gdyż grupa ta jest określana mianem „milczącej”, która nie potrafi artykułować swoich pragnień, ani zmobilizować się w celu wywalczenia polepszenia swojej sytuacji. Polityka społeczna prowadzona w sposób nieprawidłowy, z brakiem uwzględnienia dostępności osób z niepełnosprawnością do różnego rodzaju dóbr może bowiem przyczynić się do negatywnych skutków dla społeczeństwa jako całości (Baranowski 2016: 66-67) oraz wpłynąć na obniżenie jakości życia osób ze specjalnymi potrzebami.

\section{DZIAŁANIA PODEJMOWANE ZE STRONY WŁADZY RP ORAZ ICH WPEYW NA JAKOŚĆ ŻYCIA NIEPEŁNOSPRAWNYCH}

Istotnym elementem, który doprowadził do poprawy sytuacji osób niepełnosprawnych w Polsce było uchwalenie ustawy z dnia 9 maja 1991 o zatrudnieniu i rehabilitacji zawodowej osób niepełnosprawnych (Kubicki 2013: 48). Jak można przeczytać w raporcie z roku 2020, korzystne zmiany dla osób z niepełnosprawnością wprowadziła przyjęta w Polsce 19 lipca 2019 r. ustawa o zapewnianiu dostępności osobom ze szczególnymi potrzebami (Komisja Ekspertów ds. Osób Głuchych 2020: 9) która wskazuje na konieczność zapewnienia dostępu osobom niepełnosprawnym do różnych sfer życia. Ustawa podkreśliła konieczność działań do których zalicza się: niwelowanie barier architektonicznych poprzez zapewnienie wolnych od barier przestrzeni komunikacyjnych budynków, dostarczenie informacji wizualnych, dotykowych bądź głosowych dotyczących rozkładu pomieszczeń w budynku, instalację urządzeń i rozwiązań architektonicznych, które umożliwią dostęp do wszystkich niezbędnych pomieszczeń, a także zapewnienie wstępu do budynku osobie korzystającej z psa asystującego. Elementy te są niezbędne dla ułatwienia życia osobom z różnymi rodzajami niepełnosprawności ruchowej, dlatego ważne jest ich przestrzeganie przy konstrukcji budynków. Ustawa o zapewnianiu dostępności osobom ze szczególnymi potrzebami zakłada również konieczność dostosowania stron internetowych do potrzeb osób z różnymi rodzajami niepełnosprawności sensorycznej oraz umożliwienie zdalnego dostępu online do usługi tłumacza przez strony internetowe i aplikacje. W ustawie podkreśla się rolę instalacji urządzeń lub innych środków technicznych do obsługi osób słabosłyszących, takich jak pętle indukcyjne, które mają za zadanie ułatwienie 
osobom z niepełnosprawnością sensoryczną sprawnego komunikowania się z innymi. Ponadto, wyżej przytoczona ustawa zakłada, iż w sytuacji, gdy podmiot publiczny nie jest w stanie zapewnić dostępności do dóbr osobie ze szczególnymi potrzebami, podmiot ten jest obowiązany zapewnić takiej osobie dostęp alternatywny: dostęp ten może polegać na zapewnieniu osobie ze szczególnymi potrzebami wsparcia innej osoby (np. ze strony pracownika sklepu), zapewnieniu wsparcia technicznego. Niekiedy może niezbędne okazać się wprowadzenie organizacji podmiotu publicznego, która umożliwi realizację potrzeb osób z niepełnosprawnościami.

Osoby z niepełnosprawnością częściej niż osoby pełnosprawne mają problem ze znalezieniem stałego oraz satysfakcjonującego zatrudnienia - pomimo zaobserwowanego w porównaniu do lat wcześniejszych wzrostu wskaźnika aktywności zawodowej oraz wskaźnika zatrudnienia tej grupy osób, nadal spora część osób z niepełnosprawnością pozostaje bez pracy: według informacji zawartych na stronie serwisu Rzeczypospolitej Polskiej www.gov.pl, co szósta osoba z niepełnosprawnością w wieku 16 lat i więcej pozostaje aktywna zawodowo. Ponadto, aktywność zawodowa oraz wskaźnik zatrudnienia osób z niepełnosprawnością utrzymują się na niskim poziomie, który znacznie odbiega od wartości wskaźników dotyczących osób pełnosprawnych (Biuro Promocji serwisu gov.pl, Niepełnosprawni na rynku pracy. Pobrane z: https:// www.gov.pl/web/rodzina/niepelnosprawni-na-rynku-pracy). Można spotkać się także z krzywdzącymi stereotypami, które poniekąd nie dopuszczają możliwości zawodowego realizowania się osoby z niepełnosprawnością, które zostały omówione przez Maję Lipiak na spotkaniu w Katowicach dotyczącym najczęściej powielanych mitów o pracy dla osób niepełnosprawnych. Do najczęściej występujących zalicza się stereotyp, zgodnie z którym niepełnosprawne jednostki nie są zdolne do podjęcia pracy ze względu na niepełnosprawność - stereotyp ten utwierdzają stosowane przez komisję ds niepełnosprawności pojęcia przy orzekaniu stopnia niepełnosprawności, takie jak „niezdolność do pracy” Inny stereotyp zakłada, że nawet jeśli osoba mogłaby podjąć zatrudnienie, to rezygnuje z tej możliwości ze względu na wsparcie finansowe oferowane przez państwo, które nie wymaga podejmowania jakichkolwiek dodatkowych działań - postrzega się więc jednostki z niepełnosprawnością jako leniwe i mało ambitne, żyjące na koszt podatników. Kolejny stereotyp głosi, że osoby z niepełnosprawnością są w stanie podejmować jedynie mało prestiżowe, niskopłatne prace fizyczne (Lipiak M, Mity o pracy dla osób „niepełnosprawnych”. Pobrane z: https://www.youtube. com/watch?v=vyW7_Z2a7Ro). Stereotypy te są niezwykle krzywdzące: ich częste stosowanie może doprowadzić do sytuacji, w której jednostka niepełnosprawna traci wiarę we własne możliwości, a co za tym idzie - zrezygnuje z podjęcia zatrudnienia (tzw. samospełniające się proroctwo).

Ważną kwestię stanowi podejmowanie przez władze państwa różnego rodzaju działań, których celem będzie aktywizacja zawodowa osób z różnymi rodzajami niepełnosprawności oraz zapobieganie dyskryminacji tej grupy mniejszościowej przez pracodawców. W tym celu powołana została ustawa o rehabilitacji zawodowej i społecznej oraz zatrudnianiu osób niepełnosprawnych, w której zostały zapisane m.in. prawa osób niepełnosprawnych, opisane zostały warunki zatrudniania oraz możliwe sposoby wsparcia tych jednostek, których głównym celem jest wyrównanie szans osób z 
niepełnosprawnością na rynku pracy, a także zapobieganie działaniom o charakterze dyskryminacyjnym skierowanych wobec tej grupy. Przykładowe działania wymienione w ustawie obejmują m.in. oferowanie szkoleń, staży, studiów podyplomowych, przygotowania zawodowego dorosłych, bonu szkoleniowego $i$ stażowego, a także wsparcie $w$ postaci jednorazowych środki na podjęcie działalności gospodarczej, rolniczej przez osoby $z$ niepełnosprawnością. Ustawa zapewnia również wsparcie pracodawcom zatrudniającym niepełnosprawnych, co ma na celu zachęcenie pracodawców do oferowania zatrudnienia tym jednostkom (Biuro Promocji serwisu gov.pl, Niepełnosprawni na rynku pracy. Pobrane z: https://www.gov.pl/web/rodzina/niepelnosprawni-na-rynku-pracy).

Ważny aspekt życia osób z zaawansowaną niepełnosprawnością stanowi prawo do otrzymania opieki w przypadku jednostek niesamodzielnych, np. całkowicie sparaliżowanych. Przejście od medycznego modelu niepełnosprawności, w którym jest ona traktowana jako uszkodzenie organizmu będące przedmiotem zainteresowania lekarzy, w kierunku społecznego podkreślającego rolę, jakie odgrywa społeczeństwo w konstruowaniu pojęcia niepełnosprawności, a także szereg protestów, w których brały udział osoby z niepełnosprawnością oraz ich opiekunowie doprowadziły do zwiększenia uwagi osób sprawujących władzę na aspekty dotyczące opieki nad osobami z niepełnosprawnością (Biuro Promocji serwisu gov.pl, Niepełnosprawni na rynku pracy. Pobrane z: https://www.gov.pl/web/rodzina/niepelnosprawni-na-rynku-pracy). Jednym z obowiązków osób sprawujących władzę powinno być zadbanie o zapewnienie wsparcia (także finansowego) tym osobom, które taką opiekę na co dzień sprawują. Niestety, „w porównaniu do innych krajów europejskich polska polityka w zakresie opieki nad osobami niesamodzielnymi jest bardzo słabo rozwinięta [...] - szacunki Komisji Europejskiej wskazują, że w roku 2010 wydatki publiczne na opiekę w Polsce stanowiły około 0,6\% PKB, podczas gdy średnia unijna wyniosła [...] około 1,8\% PKB” (Polakowski, Szelewa 2013: 3). Państwo polskie nie zapewnia wystarczającego wsparcia finansowego osobom sprawujący opiekę nad jednostkami z niepełnosprawnością, w związku z czym wiele osób potrzebujących wsparcia pozostaje bez opieki, ponieważ ich opiekunowie są zmuszeni do podjęcia pracy zarobkowej - co doprowadza ich do konieczności niemal całkowitego wycofania się z życia ze względu na brak osoby, która udzieli pomocy w codziennych czynnościach.

Wprowadzone przez rząd Rzeczypospolitej Polskiej ustawy nie są w stanie przyczynić się do zmiany negatywnych postaw wobec jednostek z niepełnosprawnością, gdyż są one głęboko zakorzenione w umysłach ludzi. Jednostki z niepełnosprawnością, zwłaszcza widoczną na pierwszy rzut oka, często stają się obiektem wykluczenia, marginalizacji oraz dyskryminacji. Wykluczenie społeczne przybiera różne formy: może być to ograniczenie dostępu do usług, udziału w życiu społecznym, kulturalnym i politycznym, a w najbardziej ekstremalnych formach może doprowadzić do braku możliwości zaspokojenia niezbędnych potrzeb. Tego typu ograniczenia skutkują marginalizacją, czyli „życiem poza spektrum korzystnych uwarunkowań rozwoju” (Chrzanowska 2013: 63-74). Błędem jednak jest traktowanie wykluczenia jako „konsekwencję osobistych nieszczęść, gdyż są one wynikiem pewnego procesu, a nie przypisanym statusem społecznym” (Baranowski 2016: 68). Oznacza to, iż ograniczenie wynikające z niepełnosprawności nie jest tym, co powoduje wykluczenie jednostki, lecz społe- 
czeństwo poprzez swoje działania (posługiwanie się stereotypami, izolowanie się od osób z niepełnosprawnością) przyczynia się do wykluczania jednostek.

\section{UŚWIADAMIANIE SPOŁECZEŃSTWA KLUCZEM DO SUKCESU}

W życiu osób z niepełnosprawnością występuje szereg barier, które stanowią istotną kwestię w kontekście dobrobytu społecznego z tego względu, iż przyczyniają się do obniżenia jakości życia, a co za tym idzie - powodują zmniejszenie zadowolenia z życia tych jednostek. Do najczęstszych problemów w życiu osób z niepełnosprawnościami zalicza się utrudnienia architektoniczne, bariery komunikacyjne dotyczące utrudnień w komunikacji oraz bariery społeczne. Bariery społeczne są niezwykle krzywdzące dla osób niepełnosprawnych - są one skutkiem istniejących stereotypów dotyczących osób z niepełnosprawnością oraz wiążą się z negatywnym wizerunkiem tych jednostek, co przyczynia się w znacznym stopniu do marginalizacji oraz wykluczenia jednostek z widoczną oraz zaawansowaną niepełnosprawnością. Jednostki, które na co dzień nie wchodzą w interakcje z osobami niepełnosprawnymi często dystansują się od przedstawicieli tej grupy, niekiedy również posługują się negatywnymi stereotypami, zgodnie z którymi jednostki niepełnosprawne są postrzegane jako wymagające ciągłego wsparcia ze strony osób trzecich, co powoduje, iż są postrzegane jako jednostki pozbawione samodzielności (Brak autora, Niepełnosprawni - sprawni $w$ życiu. Pobrane z: https://kampaniespoleczne.pl/niepelnosprawni-sprawni-w-zy$\mathrm{ciu} /$ ) oraz przyczynia się do ich wykluczenia z życia społecznego. Takie stereotypy są niezwykle krzywdzące dla jednostek z niepełnosprawnością: nie tylko przyczyniają się do pojawienia się poczucia bycia gorszym od osób pełnosprawnych, lecz mogą w rezultacie sprawić, że jednostki te zostaną pozbawione motywacji do podejmowania jakichkolwiek działań, co tylko będzie przyczyniać się do umacniania negatywnych stereotypów. Z tego względu istotne jest, aby regularnie podejmowane były działania mające na celu uświadamianie osób pełnosprawnych czym jest niepełnosprawność, z jakimi ograniczeniami się wiąże oraz jakie działania mogą zostać podjęte w celu ułatwienia życia jednostkom $\mathrm{z}$ niepełnosprawnością. Istotną rolę $\mathrm{w}$ tego typu działaniach powinno odgrywać budowanie empatycznych postaw i walka z negatywnymi stereotypami dotyczącymi niepełnosprawności. Przykładem tego typu działań może być prowadzenie zajęć w szkołach, przeprowadzanie kampanii społecznych bądź warsztatów tematycznych dotyczących niepełnosprawności, a także popularnych w dobie pandemii webinariów. Ważna jest również aktywizacja oraz przeciwdziałanie dyskryminacji i wykluczeniu społecznemu osób z niepełnosprawnościami, które będą współfinansowane przez państwo oraz działania mające na celu zapewnienie dostępu do dóbr społecznie pożądanych (Jesiotr P., Zapobieganie wykluczeniu i przeciwdziałanie dyskryminacji osób niepełnosprawnych. Pobrane z: http://ngo.um.warszawa.pl/ otwarte-konkursy/zapobieganie-wykluczeniu-i-przeciwdzia-anie-dyskryminacji-os-b-niepe-nosprawnych). Niepełnosprawność, podobnie jak narodowość czy orientacja seksualna jest posiadaną przez te jednostki cechą, która nie powinna rzutować na sposób postrzegania tych jednostek. Nie powinno się więc postrzegać tych osób przez pryzmat ich niepełnosprawności. Nadmierna protekcjonalność, czyli ciągła chęć po- 
mocy wynikająca niejednokrotnie ze współczucia może doprowadzi do tego, że osoby te zaczną tracić wiarę we własne możliwości.

\section{BIBLIOGRAFIA}

Baranowski, Mariusz. 2015. „Etyka egoizmu a duch globalizacji. O antyspołecznych podstawach polityki społecznej”. W: P. Żuk i P. Żuk (red.). O kulturze strachu $i$ przemyśle bezpieczeństwa (ss. 115-124). Warszawa: Oficyna Naukowa.

Baranowski, Mariusz. 2016. „Socjologiczny wymiar Państwa dobrobytu”. W: M. Baranowski, P. Cichocki i M. Maraszkiewicz (red.). Przestrzeń publiczna i państwo dobrobytu (ss. 59-72). Poznań: Wydawnictwo Naukowe Wydziału Nauk Społecznych UAM.

Baranowski, Mariusz. 2019. „The Struggle for Social Welfare: Towards An Emerging Welfare Sociology.” Society Register 3(2): 7-19.

Chrzanowska, Iwona. 2013. „Niepełnosprawność a zagrożenie marginalizacją i wykluczeniem. Rozważania w kontekście teorii underclass.” Studia Edukacyjne 25: 6374.

Gleń, Piotr, Jarocka-Mikrut, \& Aleksandra. 2015. „Rola architektury w codziennym funkcjonowaniu osób niepełnosprawnych ze szczególnym uwzględnieniem osób niewidomych i niedowidzących.” Budownictwo i Architektura 14(2): 40.

Konarska, Joanna, 2019. Niepełnosprawność w ujęciu interdyscyplinarnym. Kraków: Oficyna Wydawnicza AFM.

Maciarz, Aleksandra. 2003. „Integracja edukacyjna w świetle oczekiwań i doświadczeń dzieci niepełnosprawnych.” Szkoła Specjalna 4/2003: 196-201.

Polakowski, Michał, \& Dorota Szelewa. 2013. „Niepełnosprawność: krótki przegląd międzynarodowy." W: Warszawskie debaty o polityce społecznej. 3. Warszawa: Friedrich-Ebert-Stiftung.

Rzempowska, Jadwiga. 2011. „Socjomedyczne aspekty funkcjonowania młodych osób niepełnosprawnych w środowisku wiejskim.” Rozprawa doktorska pod przewodnictwem Prof. UM dr hab. med. Alicji Krzyżaniak). Poznań: Wydawnictwo Uniwersytetu Medycznego im. Karola Marcinkowskiego.

Stelter, Żaneta. 2010. „Cierpienie a utrata sprawności.” W: Choroba, niepełnosprawność, cierpienie oraz postawy wobec nich - w teorii i badaniach. Warszawa: Wydawnictwo Akademii Pedagogiki Specjalnej.

Twardowski, Andrzej. 2018. „Społeczny model niepełnosprawności - analiza krytyczna." Studia Edukacyjne 48/2018.

Zaremba, Michał. 2016. „Dobrobyt społeczny - problemy metodologiczne i definicyjne.” Zeszyty Naukowe Polskiego Towarzystwa Ekonomicznego w Zielonej Górze 3(4): 325-326.

Zielińska-Więczkowska, Halina \& Katarzyna Ziółkowska. 2014. „Problemy życiowe osób niepełnosprawnych na tle uwarunkowań socjodemograficznych.” Medycyna 
Rodzinna 3.

Autor nieznany. 2014. „Osoba niepełnosprawna aktywnym uczestnikiem życia społecznego i zawodowego” 12-16, 21-23. Rzeszów: Regionalny Ośrodek Polityki Społecznej ROPS.

\section{Źródła internetowe}

Tamara. 2020. „Niepełnosprawność intelektualna a bariery społeczne.” W: http://www. perioorto.pl/niepelnosprawnosc-intelektualna-a-barier [dostęp: 10.12.2020].

Jesiotr P. 2020. „Zapobieganie wykluczeniu i przeciwdziałanie dyskryminacji osób niepełnosprawnych”. W: http://ngo.um.warszawa.pl/otwarte-konkursy/zapobieganie-wykluczeniu-i-przeciwdzia-anie-dyskryminacji-os-b-niepe-nosprawnych [dostęp: 11.12.2020].

Admin Rampy. „Potrzeby osób z niepełnosprawnością w zakresie pokonywania barier.” W: https://rampa.net.pl/potrzeby-osob-niepelnosprawnych-w-zakresie-pokonywania-barier [dostęp: 29.11.2020].

Autor nieznany, „Niepełnosprawni nie mogą wziąć ślubu.” W: https://www.polsatnews.pl/wiadomosc/2019-11-17/myslelismy-ze-zostaniemy-potraktowani-jak-normalna-para-niepelnosprawni-probuja-wziac-slub/ [dostęp: 10.12.2020].

Lipiak, Maja. 2020. Mity o pracy dla osób „niepełnosprawnych”, https://www.youtube. com/watch?v=vyW7_Z2a7Ro [dostęp: 18.12.2020].

Raport Komisji Ekspertów ds. Osób Głuchych pt. „Osoby Głuche w Polsce 2020. Wyzwania i rekomendacje”. W: https://www.rpo.gov.pl [dostęp: 10.12.2020].

Brak autora, „Niepełnosprawni - sprawni w życiu.” W: https://kampaniespoleczne.pl/ niepelnosprawni-sprawni-w-zyciu [dostęp: 28.11.2020].

Serwis biura rzecznika praw obywatelskich rpo.gov.pl. W: https://www.rpo.gov.pl/pl/ content/konwencja-onz-o-prawach-osob-niepelnosprawnych [dostęp: 28.11.2020]

Strona Fundacji Polskich Niewidomych i Słabowidzących „Trakt” W: http://www.trakt. org.pl/osoby-niepelnosprawne-wzrokowo-w-sklepach-samoobslugowych-dorota-koprowska-joanna-koprowska/ [dostęp: 1.12.2020]

Strona Polskiej Fundacji Osób Słabosłyszących, http://pfos.org.pl/w-swiecie-polciszy/ emocje/bariery-w-zyciu-codziennym/ [dostęp: 29.11.2020]

Strona serwisu Rzeczypospolitej Polskiej, https://www.gov.pl/web/rodzina/niepelnosprawni-na-rynku-pracy [dostęp: 29.11.2020]

Ustawa z dnia 27 sierpnia 1997 r. o rehabilitacji zawodowej i społecznej oraz zatrudnianiu osób niepełnosprawnych W: https://isap.sejm.gov.pl/ 


\section{Barriers in everyday life and their impact on the quality of life of people with disabilities}

ABSTRACT: This paper aims to identify the difficulties faced by individuals with different types of disabilities and the negative effects of these difficulties, including reduced opportunities to participate in cultural and social life, reduced access to socially desirable goods, and decreased satisfaction with life. Attention will be focused primarily on determining the impact of barriers on the lives of individuals with disabilities. To do so, I will analyse found material that includes the obstacles that they have to face and how they affect the well-being and overall life of individuals. Ways of facilitating the active participation of individuals with disabilities in society and the use of goods on an equal footing with non-disabled people will be identified, taking into account the role of the state in this aspect: the key document for ensuring access to goods for people with disabilities, i.e. the Act of 19. July 2019 on Ensuring Accessibility for Persons with Special Needs will be described.

KEYWORDS: disability, architectural barriers, social barriers, quality of life, access to goods 